\title{
The effects of surprise political events on quoted firms: the March 2004 election in Spain
}

\author{
Pau Castells • Francesc Trillas
}

Received: 26 April 2011 / Accepted: 7 October 2011 / Published online: 28 October 2011

(C) The Author(s) 2011. This article is published with open access at SpringerLink.com

\begin{abstract}
In the last days of the electoral campaign for the 2004 general election in Spain, on Thursday March 11th 2004, a series of simultaneous terror attacks caused the death of 191 persons in commuting trains in the capital Madrid. Four days later, the opposition party won the election, against all predictions that were made prior to the terror attacks. This change in expectations presents a unique opportunity to take advantage of event study techniques to test some politico-economic hypotheses. The quantitative exercise is carried out employing Seemingly Unrelated Regressions (SUR). Hypothesis testing is improved by means of bootstrapping techniques. Convergence theories prove quite resilient as, jointly, quoted firms were not significantly affected by the election outcome. The impact on politically connected companies and particular economic sectors, however, suggest that a combination of capture and agency problems may play a role in explaining the effects of the change in expectations.
\end{abstract}

Keywords Event study · Median voter · Agency $\cdot$ Capture $\cdot$ Elections · Political connections

We thank Arnau Rovira (Universitat Pompeu Fabra) for excellent research assistance during this project. We acknowledge financial support from project ECO2010-20718.

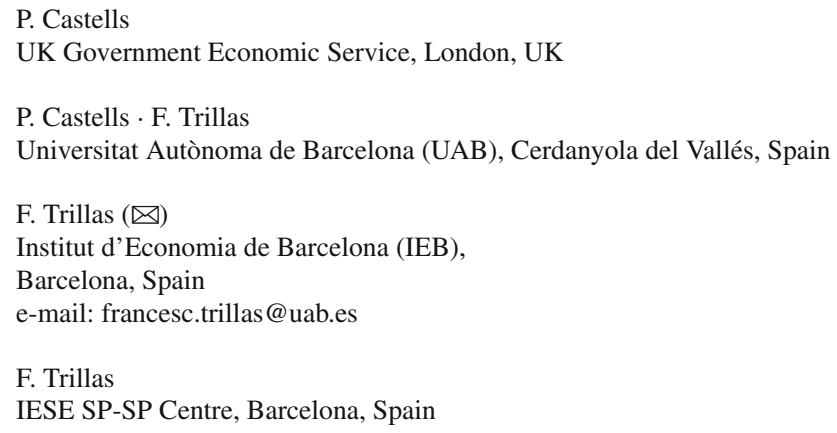




\section{JEL Classification $\quad \mathrm{G} 14 \cdot \mathrm{G} 15$}

\section{Introduction}

In the last days of the campaign for the 2004 general election in Spain, on Thursday March 11th 2004, ${ }^{1}$ a series of simultaneous terror attacks caused the death of 191 persons in commuting trains in Madrid. The attacks themselves, according to some, or a deliberate attempt by the incumbent government to hide information about the attacks for electoral reasons in the short period of time between the attacks and the election, according to others, are held responsible for the surprise victory of the Socialist opposition in the election on the next Sunday. This change in expectations presents a unique opportunity to take advantage of event study techniques ${ }^{2}$ and use the natural experiment to test some economic and politico-economic hypotheses. One of the problems of many event studies is that long event windows run the risk of including effects of events other than those under analysis; the fact that in this case the election result could not have been predicted four days before the election greatly reduces the meaningful length of the event window and hence the potential for event contamination, except for the potential confusion between the attacks themselves and political change, something we deal with in Sect. 5.

The Median Voter Theorem ${ }^{3}$ predicts that if two vote-maximizing parties compete in a single political dimension, and voter preferences are single peaked, then both parties converge presenting the platform that best suits the median voter. The theorem, an application by Downs (1957) of the Hotelling (1929) location model, tries to explain the strong forces towards convergence to the centre of the ideological spectrum that are observed in politics. The median voter theorem has been used in many applications in economics and has become one of the workhorse models of the literature on political economy (see Persson and Tabbellini 2000). However, many authors have pointed out that there is evidence that political parties often differ in some important policy dimensions, so that politics would be partisan ${ }^{4}$ instead of convergent; Roemer (2001) wonders why would a group of citizens bother to undertake the costs of creating a political party if they end up implementing the same policies as their main rival. Which of both theories does evidence support? This question may have different answers depending on time and place. We test it for one country and place were, according to political rhetoric, one would expect to find high divergence: Spain in 2004. In the months prior to the election, Prime Minister (or President of Government, as it is called in Spain, where the head of state is the King) Aznar had supported U.S. President Bush on the Irak war, for example, a move that was strongly criticized by the opposition. Socialist Party main opposition candidate José Luis R.

\footnotetext{
1 Electoral campaigns in Spain usually end on Friday, and Saturday is "reflection day." Vote is on Sunday.

2 See Binder (1985, 1998), MacKinlay (1997) and Khotari and Warner (2007).

3 See Downs (1957).

4 See Alesina and Rosenthal (1995). Petterson-Lidbom (2008) find partisan effects at the local level in Sweden, but Ferreira and Gyourko (2009) show that at the local level partisan effects of Mayoral elections in the U.S. are weaker than at the national level.
} 
Zapatero was according to some commentators to the left of previous socialist leader Felipe González. It was also a period of increasing polarization in many countries (including the US) between the main political parties. Being Spain a member of the European Union in the Euro area, however, implies that the forces of convergence are also strong, as the European Union establishes very strict norms of fiscal policy and controls monetary policy through the European Central Bank. Whether convergence or partisan forces are stronger is ultimately an empirical question.

Previous studies have analyzed the impact of elections on shareholder's expectations, and we contribute to this literature. For example, Roberts (1990), Shum (1995), Herron et al. (1999), Herron (2000), Pantzalis et al. (2000), Vuchelen (2003), Jensen and Schmith (2005), Leblang and Mukherjee (2005), Füss and Bechtel (2006) and Jayachandran (2006) find different degrees of convergence depending on time and country. Like Jayachandran (2006) we analyze the effect of a surprise political event. But we do it with econometric techniques that improve the reliability of significance tests, such as the Seemingly Unrelated Regressions method and bootstrapping.

We find that, in spite of rhetoric, investors did not expect significant differences between both major Spanish political parties. The expectation was that the degree of convergence in policies affecting the average profits of firms in the overall market would be high.

Even though our findings are consistent with the hypothesis of no impact from the change in Government on the expectations for the Spanish economy as a whole, we also test whether the surprise election result had an impact on specific sectors and politically connected businesses. If a businesses' allegiance to the incumbent political party had a positive or a negative impact on its profits, an unexpected change in Government will result in a negative (or positive) impact on the firm's financial value. The analysis shows that such hypothesis of capture of politicians by firms, in itself and combined with agency problems in privatized firms with dispersed shareholdings, is not rejected by the data. This is revealed by examining both sector and groups of individual stock price reactions to the surprise electoral result, particularly where businesses are identified as being connected to the incumbent political party.

In the rest of this paper, in Sect. 2 we provide some background on the events of interest, methodological issues and the hypotheses. In Sect. 3, we test convergence versus partisan theories looking at the joint reaction of stock prices to the surprise election result. In Sect. 4, we test some other theories that involve firm value expectations, such as capture and agency theories. Section 5 introduces some notes on the effects of the terror attacks. Finally, Sect. 6 concludes.

\section{Background}

\subsection{The events}

On Thursday March 11th 2004, a major terrorist attack killed 191 persons in commuting trains in Madrid, the Spanish capital. On Sunday March 14th 2004, the Socialist Party (PSOE) won the general election by a large though not overall majority (see Fig. 1), beating all expectations as reported by electoral polls. 


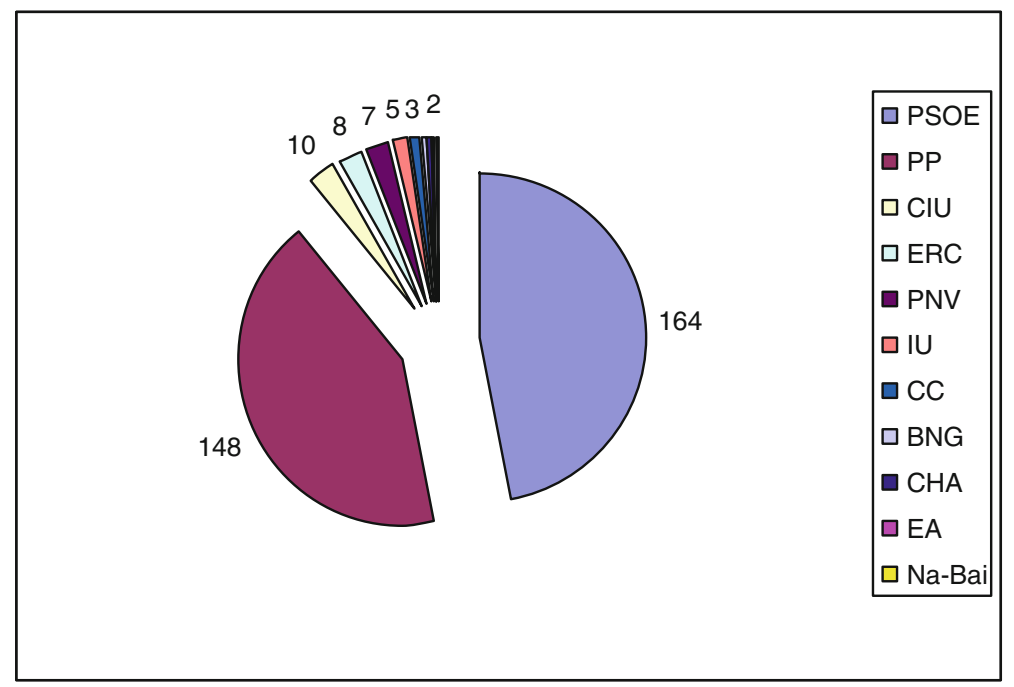

Fig. 12004 General election results. Seats in Parliament by political party

The special circumstances surrounding the Spanish general election made its final outcome completely unpredictable four days prior to the election, ${ }^{5}$ because it was then that the terrorist attacks occurred. Until that day, the ruling Popular Party (PP) had led the polls by 2 to 7 points, according to different poll sources (such as newspapers El Pais, El Mundo, ABC). In fact, according to a poll performed after the election by an official body in Spain (Centro de Investigaciones Sociológicas -C.I.S. ${ }^{6}$ ), $21.5 \%$ of voters declared being influenced by the terrorist attacks in their voting decision. More interestingly, $9.4 \%$ of voters voted for PSOE only because of the terrorist attacks, while only $1.5 \%$ of voters voted PP because of the very same reason. It is clarifying to see that the difference between these two values is $7.9 \%$. As the final results gave a 5 point advantage to the Socialist party, it leaves the results, discounting the effect of the terrorist attack on voters' decisions, in a 2.9 point lead by the $\mathrm{PP}$, which is roughly consistent with poll results prior to the terrorist attacks.

García Montalvo (2011) provides statistical evidence that indeed the attacks changed the expected result of the election. By using the postal vote, which by the electoral rules was sent by absent voters prior to the terrorist attack, as a control group, the study shows that this was significantly different from the vote on election day. The attack had an important electoral impact, rejecting the hypothesis that the identity of the winner was unaffected by the terrorist attack. To be precise, this study claims that the incumbent conservative party would have won the election, had the terrorist attack

\footnotetext{
5 The poll that gave the incumbent Popular Party (PP) the narrowest advantage among all published polls over the Socialist Party (PSOE) was published in newspaper La Vanguardia seven days before election day (polls cannot be made public by law in Spain after five days before election day, and the last ones are usually published seven days before, on the previous Sunday). According to this poll, PP was at that time two percentage points ahead of the Socialist Party.

6 Estudio Postelectoral del CIS, Marzo-Abril 2004.
} 
Table 1 From March 11 to March 14

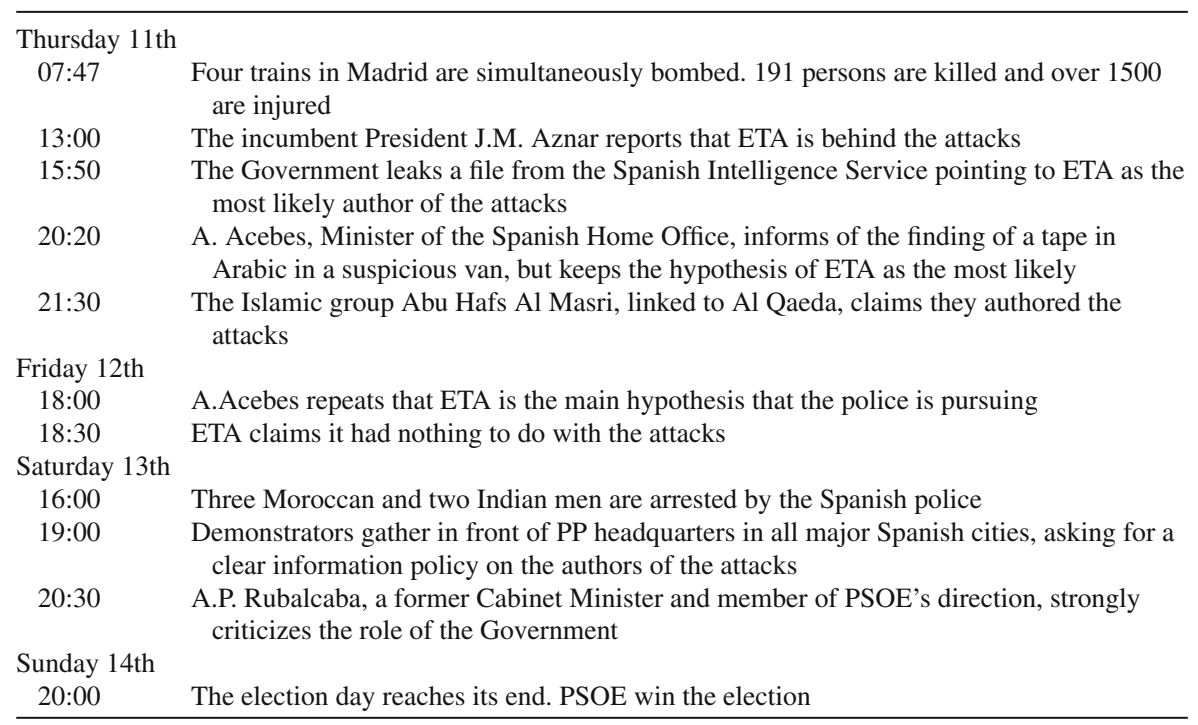

Sources El Mundo, El País

not taken place, reaching a range between 42 and $45 \%$ of the vote, while the Socialist party would have obtained $37 \%$.

Therefore, there is a strong case to hypothesise that returns on Monday morning, the day after the election took place, would incorporate the impact of an unexpected political change (if the semi-strong version of the financial markets efficiency hypothesis holds $^{7}$ ). If any company's or economic sector's profit was contingent on the political outcome of the election, their valuation must have significantly changed after the vote, as the results were not expected.

There have been many interpretations of why the terrorist attacks had such an importance in the election results. A stream of opinion suggested that the terrorist attacks confirmed the general opinion in Spain that the PP Government's decision to get involved in the Iraq war was a mistake. Opinion polls showed that almost $85 \%$ of Spaniards opposed the war in Iraq. Others argue that the main cause of the fall down of the PP was not caused by the terrorist attacks themselves, but by the management of the subsequent crisis by the incumbent Government. When the attacks occurred in the morning of Thursday 11th March 2004 (see Table 1), the initial reaction by most analysts and politicians was to blame ETA, the Basque separatist terrorist group and by far the most active terrorist group in Spain over the last 30 years. ${ }^{8}$ Nevertheless, the evidence soon pointed to Al-Qaeda and later the very same day of the attacks most international press was assum-

\footnotetext{
7 According to this version of the hypothesis, stock prices summarize all publicly available information about a particular stock. Then, only new information affects stock prices.

8 See Abadie and Gardeazábal (2003).
} 
ing that the attacks had been perpetrated by Islamist terrorist groups. Yet the PP Government kept on blaming ETA for the next four days, until the Election Day (see Table 1). Some commentators suggested that the PP feared losing the election if the public concluded that Islamist groups targeted Spain as a result of the Spanish Government's support of the Irak war. In addition, the PP focused its preelection message on the fight against ETA and on the influence of ETA's separatist objectives on nationalist forces in the periphery willing to support a new Socialist government. Therefore, following this line of reasoning, if the PP Government could hold off the three days remaining until the election blaming ETA, any negative impact on their electoral prospects would be averted and this would reinforce their campaign message. Some commentators noted that the Government was not really interested in transparently investigating the attacks, which had a large emotional impact on public opinion, but only in re-election. To many observers, this was the cause of the unexpected results on the Election Day, Sunday the 14th of March, 2004.

Being the cause of the change in citizen preferences one thing or another, the fact is that the actual results of the election were not the ones that could have been rationally anticipated by the market before the attacks occurred. If any company's or industry's profit depended on the political outcome of the election, their financial valuations were bound to have changed significantly between Thursday 11th in the morning and the opening of the stock market on Monday 15th, already after the election and the week-end break in the stock market.

\subsection{Methodology}

We carry out an analysis of the effect on the financial markets of the political change as a result of the March 2004 election in Spain. Based on the semi-strong version of the Efficient Market Hypothesis (EMH), if the political change had any effect on the discounted expected future stream of profits of quoted companies, the markets would have reacted to the new information accordingly. The special circumstances surrounding this election make this occasion a unique opportunity to test for effects of political change on the performance of specific groups of businesses and the Spanish stock market as a whole.

The classical abnormal returns computation is not suitable for analysing the effects of an event that affects a group of companies at the same moment in time. When there is event clustering ${ }^{9}$ the covariance amongst returns will not be zero, and the asymptotic results of normality no longer hold. An alternative approach is proposed by Binder (1985) which disaggregates the portfolio into a multivariate regression model system of returns equations, with one equation for each of the firms experiencing the events:

$$
R_{1 t}=\alpha_{1}+\beta_{1} R_{m t}+\sum_{a=1}^{A} \gamma_{1 a} D_{a t}+\varepsilon_{1 t}
$$

9 Events affecting different firms occur at the same moment in time. 


$$
\begin{gathered}
R_{2 t}=\alpha_{2}+\beta_{2} R_{m t}+\sum_{a=1}^{A} \gamma_{2 a} D_{a t}+\varepsilon_{2 t} \\
\vdots \\
R_{n t}=\alpha_{n}+\beta_{n} R_{m t}+\sum_{a=1}^{A} \gamma_{n a} D_{a t}+\varepsilon_{n t}
\end{gathered}
$$

where $i=1 \ldots n$ are the number of companies we include; $R_{i t}$ are company i's stock returns ${ }^{10} ; R_{m t}$ are the stock market index returns; $D_{a t}$ is a dummy variable that takes value 1 on the days of the events of interest and zero otherwise; $\alpha_{i}, \beta_{i}$, and $\gamma_{i a}$ are parameters to be estimated; and we allow the error terms $\left(\varepsilon_{11}, \ldots, \varepsilon_{1 t}, \varepsilon_{21}, \ldots\right.$, $\left.\varepsilon_{2 t}, \ldots, \varepsilon_{n 1}, \ldots, \varepsilon_{n t}\right)$ to be heteroskedastic across firms but non-correlated across time.

We estimate the model by either using the Ibex-35 index of the Madrid stock exchange as $R_{m t}(\mathrm{M} 1)$ or a constant mean returns model (M2) which implies that, from the previous equations, we remove $\beta_{i} R_{m t}$. This structure allows the coefficients to differ across firms and is an application of the seemingly unrelated regression methodology, SUR. ${ }^{11}$ This multivariate regression model assumes that the disturbances are uncorrelated within each equation but allows for the errors to be contemporaneously correlated across equations. It also presents a number of advantages compared to more standard regression models generally used in event studies. First, it can test joint hypotheses (using the Wald test for instance) while other approaches only test for average effects. Secondly, this property also allows the coefficients not to cancel out with each other when they have different signs i.e. if we want to test the joint effect of an event that causes both positive and negative effects in the different firms tested, by using an averaged time series we might conclude there is no effect as those might cancel out. By employing SUR we indeed unveil these effects as long as they are statistically significant. Finally, SUR regression allows robustly testing event windows of a reduced length by multiplying the length of the window across firms and hence increasing the available degrees of freedom.

$\overline{10}$ Daily returns can be obtained in the usual fashion

$$
r_{t}=\frac{P_{t}-P_{t-1}}{P_{t-1}}=\frac{P_{t}}{P_{t-1}}-1
$$

where $P_{t}$ stands for prices at time t. Nevertheless, we use the logarithmic transformation

$$
R_{t}=\ln \left(P_{t}\right)-\ln \left(P_{t-1}\right)
$$

where $R_{t}=\ln \left(r_{t}+1\right)$, which yields almost identical results, yet a more symmetric distribution, which is clearly convenient for the sake of the analysis as it is far easier to derive the time-series properties of additive processes (such as the natural logarithmic transformation) than of multiplicative processes.

11 This methodology is also used in a study of financial market perspectives of political expectations by Roberts (1990), without using the bootstrap technique, as we do, to improve the reliability of significance tests. 
Testing individual hypotheses is unproblematic under this framework as $t$ tests can consistently test hypotheses where restrictions are imposed in parameters estimated by SUR estimation. However, we are especially interested in testing joint hypotheses, which present some statistical challenges. Wald tests are available for this type of equation but are only valid asymptotically. In small samples, these tests are biased against the null and tend to over reject. This implies that whereas results are valid when the null hypothesis is not rejected, we need to be cautious in the interpretation of those cases where the null is rejected. Chou (2004) proposes bootstrap methods to address the over rejection problem. Using Monte Carlo simulations, he shows that bootstrapping the sample provides $p$ values very close to the nominal size of the test. The bootstrap method (Effron 1979) is a computationally intensive method that allows computing the distribution of a test statistic by re-sampling the data. ${ }^{12}$ Horowitz (2001) shows that critical values obtained from this method are always at least as accurate as standard asymptotic theory.

For the purpose of the empirical analysis we propose the following procedure: First, estimate with SUR. Second, test the hypothesis when necessary with the Wald test, and in the case a null hypothesis is rejected at the 5\% level, bootstrap the test to obtain the $p$ values by re-sampling a certain number of times. As this method is very computationally-intensive, we only compute the bootstrapped $p$ values when the null hypothesis is rejected robustly throughout the different models. Otherwise, we are conservative and understand that there is no sufficient evidence to consider the null rejected. The bootstrap method applied to the Wald test in a SUR framework is applied by following the steps below (Chou 2004):

1. Estimate the model by Ordinary Least Squares and obtain the residuals $\left(\hat{\varepsilon}_{1}, \hat{\varepsilon}_{2}, \ldots, \hat{\varepsilon}_{T}\right)$ and the parameters corresponding to the different alphas, betas and gammas. Calculate the Wald test.

2. Estimate the model by Ordinary Least Squares without the observations corresponding to the event window and obtain the parameters of the model and the residuals $\left(\hat{\varepsilon}_{1}, \hat{\varepsilon}_{2}, \ldots, \hat{\varepsilon}_{T_{1}}, \hat{\varepsilon}_{T_{2}}, \ldots, \varepsilon_{T}\right)$, where the event window comprises observations between $T_{1}$ and $T_{2}$.

3. Repeat a large number of times the following steps:

a) Draw a bootstrap sample $\varepsilon_{t}^{*}$ from the residuals in 2. Compute the values of $\left(R_{1 t}, R_{2 t}, \ldots, R_{n t}\right)$ using the parameters from 2 and the bootstrapped residuals $\varepsilon_{t}^{*}$. Call the resulting values $\left.R_{1 t}^{*}, R_{2 t}^{*}, \ldots, R_{n t}^{*}\right)$.

b) Estimate with OLS using the original independent variables data and the bootstrapped dependent variable data $\left(R_{1 t}^{*}, R_{2 t}^{*}, \ldots, R_{n t}^{*}\right)$. Calculate the Wald test and call it $\tau^{*}$.

4. Calculate the percentage of $\tau^{*}$ 's that are greater than the Wald statistic computed in 1 , which provides the bootstrap $p$ value of the test.

\footnotetext{
12 Sampling from the original sample. The idea underlying bootstrap is that we pretend that the sample is the population. Thus, we obtain bootstrap samples by sampling from the (original) sample which gives a consistent estimation of the distribution of a test statistic.
} 
This way, one can obtain reliable joint tests for the hypotheses of interest. These joint tests can be either for all the companies in the sample (Sect. 3) or for groups of them (Sect. 4).

We estimate the model for a sample of companies in the MCM (Madrid's Continuous Market) Stock Exchange. 125 companies were originally included in the data set. However, only 87 companies were finally included in the estimation. The 38 remaining companies were excluded because of either thin trading or incomplete data. The estimation period ranges from May 2003 to December 2004, therefore having a preevent window from May 2003 to March 2004, and a post-event window from March 2004 to December 2004. We use daily returns data for Spanish companies in the MCM Stock Exchange from Infomercados, a financial web site specialized in Spanish equity markets.

Two event windows are included in the estimation, an event window for the terrorist attacks and a window for the period immediately following the general election. The window for the terrorist attacks includes the day of the events, 11th of March, and the day after it, Friday the 12th. In this case the news of the terrorist attacks could not have been discounted, and therefore it does not make sense to include the day before the event as is standard practice in many event studies. There are two reasons for including this event window. In the first place, the attacks might have had an effect on the stock markets by themselves. Secondly, as they were the indirect cause for the change in the election results, economic agents might have partially discounted when the attacks occurred that the PP was going to lose the election, or more seemingly, that the probabilities of the PSOE to win the election increased. Section 5 discusses in more detail the literature on terrorism and economy and whether the empirical results are consistent with the methodological approach.

The second event window corresponds to the impact of the Spanish general election results. A three-day event window, which is usually the window length chosen for general event studies with daily data, is not the most suitable length in this case. This is because the effects of a change in a government are of a higher and deeper importance than particular events affecting a firm and it might take some days for traders to analyse and understand the nature of the change to its whole extent. We therefore prefer a five-day event window instead. For robustness of the results we roll back and forward the window presenting results for groups of companies for each model with 4, 5 and 6 days event windows (meaning returns from March 15th to 18th, 15th to 19th, and 15th to 22nd). In Sect. 3, we also test for the joint significance of the attacks plus the election as if they were a single event and we do this for windows between the day of the attacks and the next Monday (3 days), Tuesday (4 days) and so on until Monday of the following week (8 days).

Once the Wald test is computed, we proceed to compute the bootstrap $p$ values in those cases where the null hypothesis has been rejected consistently. The benchmark we use for considering a null hypothesis robustly rejected is when at least in one of the two models (M1 and M2) the null hypothesis has been rejected in the three different event windows presented (4, 5 and 6 days). If this is the case, in Sects. 4 and 5 we obtain bootstrap $p$ values at least for the 5 days case. 


\subsection{Hypotheses}

We test two general hypotheses, both related to the political economy literature (see for example Persson and Tabbellini 2000): the partisan theory of political parties and the theory of collusion between politicians and business managers, which is also linked with the theory of capture and the agency theory of a conflict of interest inside firms and in the political arena.

- Convergence versus partisanship According to the partisanship theory, political parties represent different constituencies with different interests. Due to political transaction costs, issues need to be aggregated in a few dimensions, and political parties differ in these broad dimensions. This is reflected for example in different macroeconomic policies. Historically, the macro-economic differences that were postulated assumed the existence of a trade-off between unemployment and inflation, left parties being more pro-employment and right parties being more anti-inflation (Hibbs 1977). More modernly, these macro-policies were assumed to take the form of left parties being more pro-public investment and pro-welfare state and right parties being more pro-market, pro-tax reductions or pro-supply side policies, depending on the interpretation or emphasis (see Boix 1996). If a higher inflation and a higher public deficit lead to increasing interest rates, this would have a negative impact in general on firms' profits, and we should expect a higher probability of left-wing policies being implemented causing lower stock valuations in general. Section 3 empirically tests these hypotheses.

- Political connections and capture Some authors, such as Herron et al. (1999), claim that macro-level policies may hide partisan differences at the sector or company specific level. Even if public deficits or inflation end up being very similar under right or left governments, differences in defence policies, environmental issues or other policies affecting particular industries may be significantly different. For example, using data for the 1992 US election, Herron et al. (1999) show that 15 out of 74 sectors $(20 \%)$ had a stock price performance which denoted that investors in these sectors were not indifferent between presidential candidates.

Some groups of citizens and businesses may overcome free-riding problems and organise in lobbies or interest groups to influence the policy choices of some politicians (Grossman and Helpman 2002). It is usually claimed that firm' owners or input providers may find it easier to overcome such free-riding problems than consumers, the latter being more atomised and having less at stake per capita in many policy areas. Geographical or historical reasons may also mean that the same firms or groups of firms may find it easier to access some political parties than others. Agency problems in politics (voters not perfectly controlling politicians) and inside firms with dispersed shareholdings (shareholders not perfectly controlling managers) may be at the root of collusion episodes between politicians and managers (Trillas 2004). The intensity of political connections in major Spanish firms may have been particularly prominent in Spain in 2004, as the privatization of major firms selling the assets to a dispersed shareholding facilitated the appointment of managers close to the PP government (Bel and Trillas 2005), something that a new Socialist government would possibly try to reverse. 
Additionally, in Spain in the first years of the XXI Century, one important specific industry was subject to important policy controversies: the electricity industry. This industry was experiencing a takeover wave all over Europe, triggered by the liberalization of energy at the European Union level. As a result, all major Spanish electricity firms were actors in the market for corporate control, either as targets or acquires. The two main political parties in Spain approached the issue with the objective of keeping Spanish firms under Spanish owners, but whereas the Popular Party tried to do this between 1996 and 2004 by trying to stop any takeover and any subsequent reduction in the number of firms, the Socialist party hinted during the 2004 electoral campaign that it would not block mergers between Spanish firms (see Trillas 2010). Section 4 presents the empirical results resulting from testing such hypotheses.

\section{The joint impact of the election on all the firms in the sample}

By testing the hypothesis that the attacks and the election had a significant impact on all the companies in the sample, we are effectively testing whether the surprise election following the terror attacks had a significant effect on the stock market as a whole.

In order to do this, we perform a Wald test to the dummy variables and bootstrap results when the variable results are significant due to over-rejection problems of the test in the SUR framework. ${ }^{13}$ Now the Wald test is performed to the whole of the 87 companies included. Table 2 reports the results, distinguishing between models M1 and M2 and the different event windows used. It is important to note that the goodness of fit for individual businesses regressions carried out with the M2 structure is considerably lower than with M1. We nevertheless present both outputs in the tables of results to provide evidence of the persistence (or non-persistence) of the results under different econometric specifications.

As inspection of Table 2 shows, the Wald test rejects the null hypothesis of no effect of the terror attacks across the different event windows. Nevertheless the bootstrap exercise in the 5-day event window shows that there is no statistically significant effect of the terror attacks in the market as a whole. In the case of the election effect, the asymptotical critical values of the Wald test itself already do not reject the null hypothesis of no effect in 4 out of 6 cases. In order to verify this result, we compute the bootstrap structure of the test in the other 2 cases, resulting in both cases in the confirmation of the no effect hypothesis. As a whole, one would conclude that neither the terror attacks nor the election result affected the Spanish economy as a whole. That would reject partisanship and it would be consistent with convergence theories such as the median voter theorem.

This methodology has not been used by other studies that test for the effect of political results on the stock market as a whole. Traditionally, these studies (see for example Vuchelen 2003) regress a national stock market index with dummy variables for the

13 As discussed in Sect. 2.2, we then perform the bootstrap in the 5-day window case. 
Table 2 Impact on all firms in the sample

\begin{tabular}{|c|c|c|c|c|c|c|c|}
\hline & \multirow{2}{*}{$\begin{array}{l}\text { Event window length } \\
\text { (election effect) }(\mathrm{T})\end{array}$} & \multicolumn{3}{|l|}{ M1 } & \multicolumn{3}{|l|}{ M2 } \\
\hline & & 4 days & 5 days & 6 days & 4 days & 5 days & 6 days \\
\hline \multirow[t]{3}{*}{ Terror Attacks Effect } & Wald test & 117.56 & 117.92 & 119.57 & 107.55 & 107.94 & 109.41 \\
\hline & $p$ values & 0.0162 & 0.0153 & 0.0118 & 0.0699 & 0.0637 & 0.0525 \\
\hline & Bootstrap $p$ values & - & 0.2359 & - & - & 0.3017 & - \\
\hline \multirow[t]{2}{*}{$\mathrm{T} \times \mathrm{N}$} & & 174 & 174 & 174 & 174 & 174 & 174 \\
\hline & Wald test & 116.40 & 97.33 & 102.14 & 115.17 & 97.97 & 97.96 \\
\hline \multirow[t]{2}{*}{ Election Effect } & $p$ values & 0.0194 & 0.2106 & 0.1278 & 0.0233 & 0.1978 & 0.1982 \\
\hline & Bootstrap $p$ values & 0.2470 & - & - & 0.3966 & - & - \\
\hline $\mathrm{T} \times \mathrm{N}$ & & 348 & 435 & 522 & 348 & 435 & 522 \\
\hline
\end{tabular}

Wald tests on the significance of abnormal returns in the immediate aftermath of the terrorist attacks (terror attacks effect) are always performed on two-day windows, corresponding to Thursday 11th March and Friday 12th March 2004. The table presents the results of these two-day window tests under different model specifications including election results windows of 4, 5 and 6 days

dates in which there were political events. We also did this (and it is available upon request) with mixed results: the variable for the terror attacks was significant (more on this in Sect. 5) but not the variables including the effect of the election results. However, it is doubtful in statistical terms that one can infer any conclusions from such simple approach. More specifically, one cannot invoke a central limit theorem with 2 observations (in the case of the terror attacks).

Both the election results and the bombings could have had more long-term effects on the financial returns of businesses than those that can be captured in the event windows presented above. To address this question we both tested for structural break in M1 and M2 and considered the effects of the results in stock market volatility. Results from the Chow test of structural break indicate that the impact of either the election or the terrorist attacks did not suppose a break in the time series and therefore the relation between the parameters and the dependent variables is stable both before and after the events.

The events could also have had an impact on stock market volatility. In fact we estimated a series of ARCH and GARCH regressions on the returns of the IBEX-35, and tested for an impact on the volatility during the event windows, with the results indicating a weakly significant and positive impact on volatility during the terrorist attacks window and a negative and non-significant impact for the election results window. However and as discussed above, it is statistically doubtful one can extract conclusions from such a procedure where a Central Limit theorem is invoked with 2 and 5 observations respectively.

Another possibility to analyse longer-term effects is to simply extend the event window to cover a longer period of time and therefore increase the power of the test. We considered an event window for the whole period after the events (over 200 days of trading) and the results indicate a significantly lower volatility than for the period preceding the election. It is however not possible to explain this effect on the basis of the events considered in this article, as long event windows fail to isolate the impact 
of one specific exogenous factor (the election or the bombings) and instead capture the impact of any event occurring during that period of time.

Table 3 presents the results from testing the impact of both events on the market as a whole (as in Table 2), but with a joint event window covering both the bombings and the post-election period. The table shows that the joint effects of the attacks and the election were only significant, although with border line significance levels, if we take the narrowest possible event window (two days for the pre-election window and one day for the post-election window).

Overall, the results outlined in this section only strengthen the argument that the surprise political result had no impact on the Spanish stock market as a whole even though they weakly suggest that the market reacted abnormally immediately after the bombings. We develop this argument further in Sect. 4. The findings however do not rule out an impact on specific economic sectors or on some businesses politically connected to either PP or PSOE. The following section introduces the methodological approach to testing these hypotheses and presents its results.

\section{Testing the impact of political connections using individual companies' or sectors' expectations}

\subsection{Impact on economic sectors}

Political partisanship implies that different parties have different visions about the priorities of the country and, in the equilibrium of the platform setting game, they run with different platforms into the elections, and the platform of the winning party is implemented. For example, a hypothetical partisan industrial policy of the Spanish Socialist party could be a will to restructure the electricity market in Spain, attaining a higher concentration of firms and creating 'national champions' in the electricity market, capable of competing in the European Energy Market, due to come into force in June 2007. We do not imply with this that PSOE favours 'national champions' while PP does not. In fact, the PP Government (1996-2004) threatened to use its golden share to stop the merger of Telefónica with the Dutch company KPM. Bel and Trillas (2005) find evidence in this particular case that this Government's veto was not driven by a will to protect Telefónica's shareholders, but by the fear of losing its residual control over the company. The partisan hypothesis is not about PSOE generally favouring 'national champions' and PP not. It is contingent specifically to the electricity sector, as the PP Government had committed itself on keeping the number of companies in the electricity market, and had honoured the commitment by stopping any merger. The arrival of a PSOE government might have caused a change on the prospects of the sector, by making possible the completion of successful transactions in the market for corporate control.

If this were the case, then again the political change in Spain on March 2004 would have caused abnormal returns on the electricity sector as a whole, as the effect of a prospective partisan policy of the socialist party in the electricity sector would have caused the returns to differ from zero, negatively or positively depending on the market's estimate of this policy's effects. 


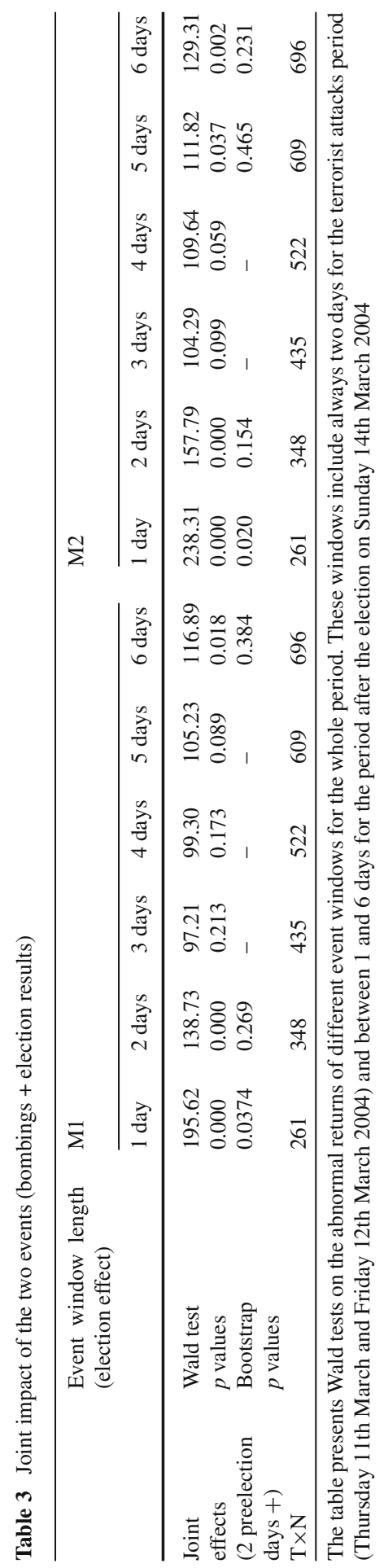


We test whether whole economic sectors are affected by partisan policies, much in the same way as it is done in Herron (2000) for the American economy. ${ }^{14}$ Using the Wald test, we formulate for every sector in the Spanish economy the following hypothesis:

$$
\left[\begin{array}{l}
H_{0}: \gamma_{1 a}=\gamma_{2 a}=\cdots=\gamma_{s a}=0 \\
H_{A}: N_{o} H_{0}
\end{array}\right.
$$

where $i=1 \ldots s$, and $s$ is the number of companies in a particular sector, while the gammas are the parameter coefficients related to the political change event window.

We use the official industry division of the MCM Stock Exchange to test for the hypothesis that a particular sector was affected by the election results (see Appendix Table 10 for a breakdown of companies by sector). Table 4 shows that the only economic sector where the null hypothesis is rejected in all cases is the electricity and gas sector. In this sector, in 5 cases the null is rejected at the $1 \%$ confidence interval and in one case at the 5\% confidence interval. The bootstrap $p$ values in Table 8 confirm such levels of significance for the rejection of the null hypothesis. This result is consistent with the hypothesis that the winners had a partisan interest in changing the structure of the electricity and gas market. However, as Appendix Table 11 shows, some of the companies covered in this sector were also politically connected to the incumbent Government. This poses the question of whether the observed impact on their financial returns was due to the different policy platforms in which the two political parties were running the election in regards to the electricity sector or whether the abnormal returns observed reflect the impact on some of the businesses in the sector from losing political connections to the incumbent Government. Section 4.2 explores this further by specifically analysing the impact on politically connected businesses.

The media sector is affected in 5 out of 6 cases, but only at the $10 \%$ confidence level using the standard asymptotic critical values. The bootstrap $p$ values show that with M1 the effects are not statistically significant while using M2 they remain significant at the $10 \%$ confidence interval. However, as discussed in Sect. 3, our confidence in M2 is substantially lower than in M1, given the low goodness of fit of the model to the data, and therefore we cannot draw firm conclusions from this marginal significance level. This result might also express the fact that relevant companies in the sector such as Recoletos, Telecinco or Antena3 were missing data and could not be included in the regression model. This resulted in only three companies being included, two of them closely related one to another (Prisa and Sogecable), and commonly considered to be connected to the Socialist party.

\footnotetext{
14 We also test whether political change had a significant effect on each company separately. We perform the $t$ test on all companies included in the estimation (available upon request). Only 3 companies out of a sample of 87 have significant abnormal returns robust to the estimation with both M1 and M2 and the different size of the event windows: Iberpapel, a paper company, Endesa, and Red Eléctrica Española, the two latter ones both electricity companies. Endesa has in all the 6 cases negative abnormal returns at the $1 \%$ confidence interval.
} 
Table 4 Effect of the election results on specific industries: Wald test

\begin{tabular}{|c|c|c|c|c|c|c|c|c|c|}
\hline \multirow[t]{2}{*}{ Event window length } & \multicolumn{3}{|l|}{ M1 } & \multicolumn{3}{|l|}{ M2 } & \multicolumn{3}{|l|}{$\mathrm{N} \times \mathrm{T}$} \\
\hline & 4-days & 5-days & 6-days & 4-days & 5-days & 6-days & 4-days & 5-days & 6-days \\
\hline Oil & NoRHo & NoRHo & NoRHo & NoRHo & NoRHo & NoRHo & 8 & 10 & 12 \\
\hline $\begin{array}{l}\text { Electricity } \\
\text { and gas }\end{array}$ & $\mathrm{RHo} * * *$ & $\mathrm{RHo} * * *$ & RHo** & $\mathrm{RHo} * * *$ & $\mathrm{RHo} * * *$ & $\mathrm{RHo} * * *$ & 24 & 30 & 36 \\
\hline Water and others & - & - & - & - & - & - & - & - & - \\
\hline $\begin{array}{l}\text { Minerals, } \\
\text { metals and } \\
\text { transformation } \\
\text { of metal products }\end{array}$ & NoRHo & NoRHo & NoRHo & NoRHo & NoRHo & NoRHo & 8 & 10 & 12 \\
\hline Machinery goods & NoRHo & NoRHo & NoRHo & NoRHo & NoRHo & RHo** & 20 & 25 & 30 \\
\hline Construction & NoRHo & NoRHo & NoRHo & NoRHo & NoRHo & RHo** & 20 & 25 & 30 \\
\hline $\begin{array}{l}\text { Construction } \\
\text { materials }\end{array}$ & NoRHo & NoRHo & NoRHo & NoRHo & NoRHo & NoRHo & 8 & 10 & 12 \\
\hline $\begin{array}{l}\text { Chemical } \\
\text { industry }\end{array}$ & - & - & - & - & - & - & - & - & - \\
\hline Engineering & - & - & - & - & - & - & - & - & - \\
\hline Aerospacial & - & - & - & - & - & - & - & - & - \\
\hline $\begin{array}{l}\text { Food and } \\
\text { beverages }\end{array}$ & NoRHo & NoRHo & NoRHo & NoRHo & NoRHo & NoRHo & 24 & 30 & 36 \\
\hline Clothes & NoRHo & NoRHo & NoRHo & NoRHo & NoRHo & NoRHo & 16 & 20 & 24 \\
\hline $\begin{array}{l}\text { Paper and } \\
\text { graphic arts }\end{array}$ & NoRHo & NoRHo & NoRHo & RHo* & NoRHo & NoRHo & 20 & 25 & 30 \\
\hline Cars & - & - & - & - & - & - & - & - & - \\
\hline $\begin{array}{l}\text { Pharmaceutical } \\
\text { and Biotechnology }\end{array}$ & NoRHo & NoRHo & NoRHo & NoRHo & NoRHo & NoRHo & 16 & 20 & 24 \\
\hline $\begin{array}{l}\text { Other } \\
\text { consumption goods }\end{array}$ & NoRHo & NoRHo & NoRHo & NoRHo & NoRHo & NoRHo & 8 & 10 & 12 \\
\hline $\begin{array}{l}\text { Tourism and } \\
\text { entertainment }\end{array}$ & NoRHo & NoRHo & NoRHo & NoRHo & NoRHo & NoRHo & 12 & 15 & 18 \\
\hline Trade & - & - & - & - & - & - & - & - & - \\
\hline Media & RHo* & RHo* & RHo* & RHo* & RHo* & NoRHo & 12 & 15 & 18 \\
\hline $\begin{array}{c}\text { Transport and } \\
\text { distribution }\end{array}$ & NoRHo & NoRHo & NoRHo & NoRHo & NoRHo & NoRHo & 8 & 10 & 12 \\
\hline $\begin{array}{l}\text { Highways and } \\
\text { parkings }\end{array}$ & NoRHo & NoRHo & NoRHo & NoRHo & NoRHo & NoRHo & 8 & 10 & 12 \\
\hline Other services & - & - & - & - & - & - & - & - & - \\
\hline Banking & NoRHo & NoRHo & NoRHo & NoRHo & NoRHo & NoRHo & 44 & 55 & 66 \\
\hline Insurance & NoRHo & NoRHo & NoRHo & RHo* & RHo* & RHo* & 8 & 10 & 12 \\
\hline Financial & - & - & - & - & - & - & - & - & - \\
\hline $\begin{array}{l}\text { investment } \\
\text { Real Estate }\end{array}$ & NoRHo & NoRHo & NoRHo & NoRHo & NoRHo & NoRHo & 16 & 20 & 24 \\
\hline $\begin{array}{l}\text { Telecommuni } \\
\text { cations }\end{array}$ & NoRHo & NoRHo & NoRHo & RHo* & NoRHo & NoRHo & 16 & 20 & 24 \\
\hline $\begin{array}{l}\text { Electronics } \\
\text { and software }\end{array}$ & NoRHo & NoRHo & RHo* & RHo** & RHo* & $\mathrm{RHo} * * *$ & 8 & 10 & 12 \\
\hline
\end{tabular}

H0: No effect on the sector for the election results

RHo (Null Hypothesis is rejected). NoRHo (Null Hypothesis is not rejected)

When in a certain sector there are not at least two companies, Wald test is not performed

Values under $\mathrm{N} \times \mathrm{T}$ indicate the number of observations available for the testing of the hypothesis in each case

$* * * 1 \%$ confidence interval; $* * 5 \%$ confidence interval; * $10 \%$ confidence interval 


\subsection{Testing the impact of political connections}

Any theory making predictions about the determinants of firm's profits, be these regulatory policies, movements in the corporate control market, managerial or rivals' decisions, etc., can be tested by an event study, if the event is not anticipated. Partisan versus convergence theories are certainly not the only ones that can be tested. We focus here on the potential of this event study to shed light on capture and agency theories relating to the relationship between firms and politicians in Spain.

This part of the exercise is related to the literature on political connections, which emerged from the pioneering contributions by Fisman (2001) and Faccio (2006). The latter constructs a database, including over 20,000 publicly-traded firms in 47 countries, reporting about members of boards of directors that have a previous or subsequent experience in politics, and documents a significant increase in corporate value when those involved in politics enter the business sector. Fisman (2001) shows that firms linked to the Suharto family experienced a significant decrease in shareholder value when news negatively associated to the dictator's health were known. Since then, a number of studies have computed the economic advantages for firms' shareholders of being connected at the board level with politicians. For example, Ferguson and Voth (2008) show that firms connected to the Nazi party experienced positive abnormal returns associated to the rise of Hitler's party to the German government. ${ }^{15}$

Elsewhere (see Bel and Trillas 2005) it has been suggested that corporate governance in large Spanish firms give a lot of discretion to managers, and that they may take advantage of this great discretion by sharing rents with politicians in exchange for favours to political parties, in the form of appointing party cronies, funding media empires or supporting particular policies. In this case, an unexpected change in the ruling party implies a break in long term collusion contracts and possibly the signing of new contracts, for example by favouring the government the appointment of new managers through pressures over key shareholders.

Agency problems may explain the fact that society is not fully able of controlling politicians, who can take decisions seeking particular and not general interests. Bel and Trillas (2005) find evidence consistent with collusion between the PP Government (1996-2004) and the managers of Telefónica, a telecommunications firm. Other state-owned companies where this type of collusion between managers and politicians could have happened were privatised as well during the PP government. If this were the case, abnormal returns would have been experienced in these companies when the PSOE won the election.

In order to test the impact of the election on politically connected businesses, we searched on the archives of Google News for press articles containing references to Board Members of companies in the sample of this article at the time when the surprise political result occurred. ${ }^{16} 46$ of the 87 companies resulted in having at least one politically connected Board Member. We then classify connections according to their strength in four different categories:

\footnotetext{
15 Other examples of this literature are Boubakri et al. (2008) and Goldman et al. (2008).

16 Search performed over the period July 2010-November 2010. The original press articles are available under request.
} 
1. Former Minister/Junior Minister/Position of high responsibility in a Government (either National or Regional Government)/Senior member of a political party.

2. Appointed to manage or lead a public company/Held other senior positions either in Government or in private sector as appointed by Government.

3. Has very clear links to, is close to, a political party.

4. Reported links to a political party but such relationship is not irrefutable.

There are several ways in which we could define a company to be politically connected. In the broadest possible definition we could define as connected any of the 46 companies which were identified as having a connection of any degree (1-4). However this approach would define as equally connected a company with most Board members being connected with degree 1 and a company with one connection of degree 4 . Because we only want to identify as connected those companies where the evidence of political connection is stronger, we establish stricter conditions and provide four different definitions for a company being considered as connected, being (a) the most restrictive definition and (d) the most relaxed:

(a) At least 4 Board Members are connected with a strength of connection categorised as 1 or 2

(b) At least $25 \%$ of Board Members are connected with a strength of connection categorised as 1 or 2

(c) At least 4 Board Members are connected with any strength of connection (1-4)

(d) At least $25 \%$ of Board Members are connected with any strength of connection $(1-4)$

Companies resulting as connected under each category (see Appendix Table 11) are then tested for abnormal returns following the election with the two standard models of financial returns (M1 and M2) and different lengths of event windows for the election results (4-6 days).

Table 5 presents the results from running a Wald test on the financial returns of both connected and non-connected businesses during the post-election window as in (3). The results of the test show significant abnormal returns for connected companies when asymptotic $p$ values are taken into account. Significance levels are $1 \%$ when $\mathrm{T}=4$ and vary between 1 and $10 \%$ when $\mathrm{T}=6$. Due to the problems of over rejection of the Wald test under the SUR framework outlined in Sect. 2, we also calculate the bootstrap significance levels of the abnormal returns in those cases where the null hypothesis of no abnormal returns is rejected when $\mathrm{T}=5$. The results are less concluding after calculating bootstrap $p$ values as even though the test rejects the null hypothesis in most groupings, significance levels are lower at between 5 and $10 \%$ confidence interval levels. Therefore we can only say that there is some weak evidence that the profit expectations of connected businesses were impacted by the surprise political result.

Connected companies as identified so far include companies connected either to PSOE, PP or to both parties, hence results may disguise that only companies connected to one party experienced a change in their profits expectations as a result of the surprise political change. To explore this further, for politically connected companies we establish whether the company is connected to PSOE, PP or whether it has connections to both parties. We define a company as connected to PP (PSOE) if more than 
Table 5 Impact of the election results on politically connected firms (Wald test asymptotic and bootstrap $p$ values)

\begin{tabular}{|c|c|c|c|c|c|c|c|c|}
\hline \multirow[t]{2}{*}{ Grouping } & \multirow[t]{2}{*}{ Type of business } & \multicolumn{3}{|l|}{ M1 } & \multicolumn{3}{|l|}{ M2 } & \multirow[t]{2}{*}{$\mathrm{N}$} \\
\hline & & $\mathrm{T}=4$ & $\mathrm{~T}=5$ & $\mathrm{~T}=6$ & $\mathrm{~T}=4$ & $\mathrm{~T}=5$ & $\mathrm{~T}=6$ & \\
\hline \multirow[t]{3}{*}{ a } & Non-connected & 0.5105 & 0.8667 & 0.5863 & 0.3891 & 0.83 & 0.4196 & 79 \\
\hline & Connected & 0.0045 & 0.0028 & 0.0314 & 0.0013 & 0.0015 & 0.0055 & 8 \\
\hline & Bootstrap $p$ values & & 0.0201 & & & 0.0304 & & \\
\hline \multirow[t]{3}{*}{$\mathrm{b}$} & Non-connected & 0.5303 & 0.924 & 0.5862 & 0.441 & 0.9046 & 0.4209 & 76 \\
\hline & Connected & 0.0015 & 0.0008 & 0.0243 & 0.0005 & 0.0005 & 0.0055 & 11 \\
\hline & Bootstrap $p$ values & & 0.0264 & & & 0.0284 & & \\
\hline \multirow[t]{3}{*}{$\mathrm{c}$} & Non-connected & 0.6917 & 0.8639 & 0.6626 & 0.5864 & 0.8434 & 0.504 & 72 \\
\hline & Connected & 0.0029 & 0.0141 & 0.0799 & 0.001 & 0.0084 & 0.0219 & 15 \\
\hline & Bootstrap $p$ values & & 0.1068 & & & 0.0677 & & \\
\hline \multirow[t]{3}{*}{$\mathrm{d}$} & Non-connected & 0.593 & 0.8782 & 0.6611 & 0.4669 & 0.8497 & 0.5123 & 65 \\
\hline & Connected & 0.0045 & 0.0172 & 0.0985 & 0.0019 & 0.0122 & 0.0349 & 22 \\
\hline & Bootstrap $p$ values & & 0.0962 & & & 0.0976 & & \\
\hline
\end{tabular}

Bootstrap $p$ values are calculated for $\mathrm{t}=5$ if significant abnormal returns are encountered for a particular grouping of companies

Table 6 Impact of the election results on PP connected, PSOE connected and mixed strategy businesses (asymptotic and bootstrap Wald test $p$ values)

\begin{tabular}{|c|c|c|c|c|c|c|c|c|}
\hline \multirow[t]{2}{*}{ Grouping } & \multirow[t]{2}{*}{ Type of business } & \multicolumn{3}{|l|}{ M1 } & \multicolumn{3}{|l|}{ M2 } & \multirow[t]{2}{*}{$\mathrm{N}$} \\
\hline & & $\mathrm{T}=4$ & $\mathrm{~T}=5$ & $\mathrm{~T}=6$ & $\mathrm{~T}=4$ & $\mathrm{~T}=5$ & $\mathrm{~T}=6$ & \\
\hline \multirow[t]{4}{*}{ a } & PP connected & 0.0002 & 0.0001 & 0.0049 & 0.0001 & 0.0001 & 0.0006 & 4 \\
\hline & PSOE connected & 0.9196 & 0.6366 & 0.3863 & 0.3286 & 0.3005 & 0.0701 & 1 \\
\hline & Mixed strategy & 0.8873 & 0.9333 & 0.7359 & 0.7257 & 0.7646 & 0.2686 & 3 \\
\hline & Bootstrap $p$ values & & 0.0028 & & & 0.0042 & & \\
\hline \multirow[t]{4}{*}{$\mathrm{b}$} & PP connected & 0.0001 & 0.0001 & 0.0054 & 0.0000 & 0.0000 & 0.0011 & 6 \\
\hline & PSOE connected & 0.6617 & 0.8846 & 0.7411 & 0.9322 & 0.5853 & 0.7517 & 1 \\
\hline & Mixed strategy & 0.7045 & 0.4482 & 0.5597 & 0.7463 & 0.4761 & 0.2694 & 3 \\
\hline & Bootstrap $p$ values & & 0.0028 & & & 0.01 & & \\
\hline \multirow[t]{4}{*}{$\mathrm{c}$} & PP connected & 0.001 & 0.0027 & 0.0443 & 0.0004 & 0.0014 & 0.0086 & 9 \\
\hline & PSOE connected & 0.8532 & 0.7489 & 0.5477 & 0.3091 & 0.3818 & 0.0883 & 2 \\
\hline & Mixed strategy & 0.4713 & 0.8191 & 0.5769 & 0.1795 & 0.5782 & 0.1416 & 4 \\
\hline & Bootstrap $p$ values & & 0.0212 & & & 0.0053 & & \\
\hline \multirow[t]{4}{*}{$\mathrm{d}$} & PP connected & 0.0005 & 0.0011 & 0.0276 & 0.0002 & 0.0006 & 0.006 & 12 \\
\hline & PSOE connected & 0.9085 & 0.903 & 0.7411 & 0.4762 & 0.5853 & 0.1814 & 3 \\
\hline & Mixed strategy & 0.6116 & 0.7805 & 0.7246 & 0.1953 & 0.4727 & 0.2498 & 6 \\
\hline & Bootstrap $p$ values & & 0.0349 & & & 0.0174 & & \\
\hline
\end{tabular}

$70 \%$ of Connected Board Members are connected to PP (PSOE). If less than $70 \%$ of Board Members are connected to any one given party we define the company as being connected with a mixed strategy. We then run specific Wald tests for companies connected to PP, PSOE or with a mixed strategy. Where the null hypothesis of no significant impact is rejected, we obtain bootstrap $p$ values for the 5-day event window as in Sect. 3 to overcome the over rejection problems (Table 6). 
The results indicate that businesses connected to the incumbent political party experienced strong abnormal returns after the election, with confidence intervals of bootstrap $p$ values being statistically significant at the $1-5 \%$ level depending on the model and grouping used in the test. Non-connected businesses, businesses connected to the opposition party and businesses connected to both PP and PSOE did not experience significant abnormal returns.

It has to be noted that we have a limited amount of data available for testing the hypotheses in some of the Wald tests presented in Table 7. However tests performed on companies connected to PP generally have a sufficiently large number of observations, between 30 in grouping $1(\mathrm{~T}=5$ and $\mathrm{N}=6)$ and 60 in grouping $4(\mathrm{~T}=5$ and $\mathrm{N}=12$ ). This, combined with the persistence of the statistical significance of the results under different regression models, event windows, groupings of companies, and asymptotic and bootstrap significance levels reinforces the robustness of the results.

The expectation of a potential change in the value of political connections for PP connected companies seems therefore to be at the root of the abnormality of the returns during the election window. The results from the Wald test identify that the behaviour of stock market returns is significantly abnormal but they do not provide information on whether this impact is positive or negative. As outlined at the beginning of this section, capture and political connections, jointly with agency problems within companies, suggest that a company losing political connections to the Government may have either a positive or a negative impact on a company's prospects of profitability. On the one hand, if society is not fully able of controlling politicians these may then collude with some businesses providing a private benefits to these businesses' shareholders. If this were the case, we would expect businesses connected to the PP to experience abnormal negative returns as a result of the surprise election result. On the other hand, if in addition to agency problems between society and politicians there are agency problems between managers and shareholders, managers could collude with politicians to the detriment of both shareholders and citizens. In such case a change in Government could produce positive abnormal returns.

As $t$ tests for individual companies cannot be robustly performed given the low number of observations available (between 4 and 6 for each company in the postelection window) it is not possible to robustly answer this question with the data available to us. We did perform such tests anyway and these showed negative and significant effects for some PP-connected companies (e.g. Endesa) and positive and significant for others (e.g. Iberia). This may suggest that both factors may have had a role in explaining the abnormal returns observed for PP connected businesses in the aftermath of the election. Figure 2 illustratively shows the financial returns of some of the largest PP-connected companies during the post-election window against the returns of the IBEX-35 stock market index.

Finally, there might be several reasons why a change in Government had only an impact on the financial returns of businesses connected to the incumbent party but not to businesses connected to the opposition party or to businesses connected to both parties. In the first place, whereas it may be possible for traders to understand the value to a particular company of being politically connected to the incumbent party, it may take some more time to obtain reliable information on the financial value of 
Table 7 Effect of the terrorist attacks on economic sectors: Wald test

\begin{tabular}{|c|c|c|c|c|c|c|c|}
\hline \multirow[t]{2}{*}{ Event window length } & \multicolumn{3}{|l|}{ M1 } & \multicolumn{3}{|l|}{ M2 } & \multirow[t]{2}{*}{$\mathrm{N} \times \mathrm{T}$} \\
\hline & 4-days & 5-days & 6-days & 4-days & 5-days & 6-days & \\
\hline Oil & NoRHo & NoRHo & NoRHo & RHo** & $\mathrm{RHo} * *$ & RHo** & 4 \\
\hline Electricity and gas & RHo** & RHo** & RHo** & $\mathrm{RHo} * * *$ & $\mathrm{RHo} * * *$ & RHo*** & 12 \\
\hline Water and others & - & - & - & - & - & - & - \\
\hline $\begin{array}{l}\text { Minerals, metals and } \\
\text { transformation of metal } \\
\text { products }\end{array}$ & RHo*** & RHo*** & $\mathrm{RHo} * * *$ & RHo*** & $\mathrm{RHo} * * *$ & $\mathrm{RHo} * * *$ & 4 \\
\hline Machinery goods & NoRHo & NoRHo & NoRHo & NoRHo & NoRHo & NoRHo & 10 \\
\hline Construction & - & - & - & - & - & - & 10 \\
\hline Construction materials & NoRHo & NoRHo & NoRHo & RHo* & RHo* & RHo* & 4 \\
\hline Chemical industry & - & - & - & - & - & - & - \\
\hline Engineering & - & - & - & - & - & - & - \\
\hline Aerospacial & - & - & - & - & - & - & - \\
\hline Food and beverages & NoRHo & NoRHo & NoRHo & RHo** & RHo** & RHo** & 12 \\
\hline Clothes & NoRHo & NoRHo & NoRHo & NoRHo & NoRHo & NoRHo & 8 \\
\hline Paper and graphic arts & NoRHo & NoRHo & NoRHo & NoRHo & NoRHo & NoRHo & 10 \\
\hline Cars & - & - & - & - & - & - & - \\
\hline $\begin{array}{l}\text { Pharmaceutical and } \\
\text { Biotechnology }\end{array}$ & NoRHo & NoRHo & NoRHo & NoRHo & NoRHo & NoRHo & 8 \\
\hline $\begin{array}{l}\text { Other consumption } \\
\text { goods }\end{array}$ & NoRHo & NoRHo & NoRHo & RHo* & $\mathrm{RHo}^{*}$ & RHo* & 4 \\
\hline $\begin{array}{l}\text { Tourism and } \\
\text { entertainment }\end{array}$ & $\mathrm{RHo} * * *$ & $\mathrm{RHo} * * *$ & $\mathrm{RHo} * * *$ & $\mathrm{RHo} * * *$ & $\mathrm{RHo} * * *$ & $\mathrm{RHo} * * *$ & 6 \\
\hline Trade & - & - & - & - & - & - & - \\
\hline Media & NoRHo & NoRHo & NoRHo & NoRHo & NoRHo & NoRHo & 6 \\
\hline $\begin{array}{c}\text { Transport and } \\
\text { distribution }\end{array}$ & NoRHo & NoRHo & NoRHo & RHo** & RHo** & RHo** & 4 \\
\hline Highways and parkings & NoRHo & NoRHo & NoRHo & NoRHo & NoRHo & NoRHo & 4 \\
\hline Other services & - & - & - & - & - & - & - \\
\hline Banking & NoRHo & NoRHo & NoRHo & NoRHo & NoRHo & NoRHo & 22 \\
\hline Insurance & NoRHo & NoRHo & NoRHo & NoRHo & NoRHo & NoRHo & 4 \\
\hline Financial investment & - & - & - & - & - & - & - \\
\hline Real Estate & NoRHo & NoRHo & NoRHo & NoRHo & NoRHo & NoRHo & 8 \\
\hline Telecommunications & NoRHo & NoRHo & NoRHo & RHo* & RHo* & RHo* & 8 \\
\hline $\begin{array}{l}\text { Electronics and } \\
\text { software }\end{array}$ & NoRHo & NoRHo & NoRHo & NoRHo & NoRHo & NoRHo & 4 \\
\hline Technological hardware & - & - & - & - & - & - & - \\
\hline
\end{tabular}

H0: No effect on the sector for the terrorist attacks

RHo (Null Hypothesis is rejected). NoRHo (Null Hypothesis is not rejected)

When in a certain sector there are not at least two companies, Wald test is not performed

Values under $\mathrm{N} \times \mathrm{T}$ indicate the number of observations available for the testing of the hypothesis in each case

$* * * 1 \%$ confidence interval; $* * 5 \%$ confidence interval; $* 10 \%$ confidence interval

connections to a new Government. Secondly, loss aversion bias, as identified in the behavioural finance literature (see Tversky and Kahneman 1991), may have played a role in explaining that businesses losing a political connection were penalised more heavily than businesses gaining political connections to the new Government. Finally, it needs to be noted that at the point the election took place, only a limited number 


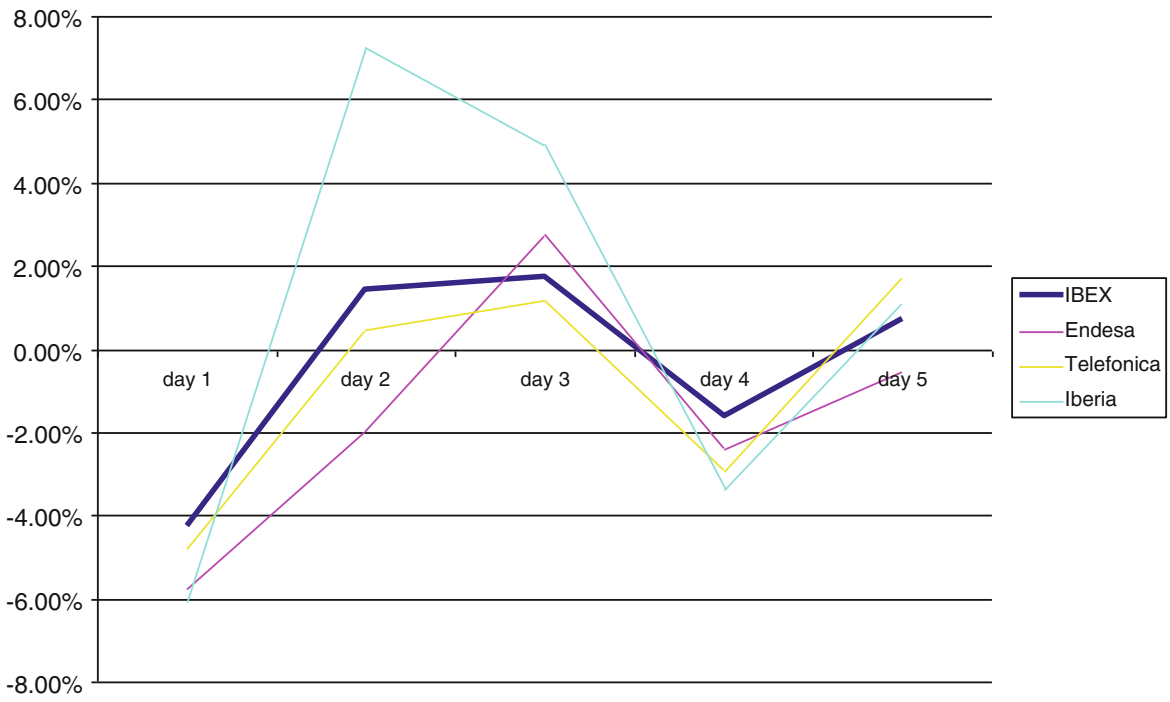

Fig. 2 Financial returns after the election for selected PP-connected businesses

of companies where connected to the opposition party, hence reducing the power of the Wald test. The number of companies connected to the PSOE range from 1 to 3 under the different specifications, with a window of $\mathrm{T}=5$ meaning the test is run with only 5 to 15 observations. As Appendix Table 11 shows, the number of companies connected to the incumbent political party when the election took place was considerably larger. For example, during the PP Government six large companies were privatised-Telefónica (which afterwards spun-off Telefónica móviles), Argentaria (which became after a merger BBVA), Iberia, Altadis, Endesa and Repsol—, with most of them being identified as connected to PP in our analysis.

\section{A remark on the effects of the terrorist attacks}

The terrorist attacks in Madrid on March 112004 had a potential double effect on the economy. First, the attacks might have directly affected certain economic sectors. Second, the attacks might have had the effect of increasing the probability of PSOE winning the election, and therefore if any company or group of companies were affected (positively or negatively) by the change of government, the effect of the terrorist attacks on their returns would have been different from zero. This is why in our model we used two different event windows (one for the terrorist attacks, another for the election results), in order to avoid considering as consequences of the election results something that was directly related to the attacks themselves. In this short section, we want to show this double effect of the attacks with an example of its effect on specific industries and show how the proposed approach of using two separate windows is largely successful in isolating the direct impacts of the terrorist attacks and the direct impacts of a change in Government. 
The literature on the effects of terrorist attacks on the economy ${ }^{17}$ points towards a negative impact of terrorism on overall economic growth ${ }^{18}$ and also some specific impacts on particular economic sectors. A considerable attention has been paid to the significant and negative impact of terrorist attacks on the tourist sector, for example in Enders and Sandler (1991), Enders et al. (1992) and Richardson et al. (2007). A negative effect on foreign direct investment has also been reported by scholars, for example in Enders and Sandler (1996) and Abadie and Gardeazábal (2008). Finally, Abadie and Dermisi (2008) analyze the impact of terrorist attacks on the office real estate markets in large financial centers, their results suggesting that economic activity in Central Business Districts can be greatly affected by changes in the perceived level of terrorism.

Table 7 presents the effects of the attacks by industry as in Table 4 . Table 8 presents the bootstrap $p$ values for those industries where the null hypothesis of no effect of the terrorist attacks is rejected robustly. Three industries are identified as affected by the terrorist attacks: Tourism and entertainment, Minerals, metals and transformation of metal products and Electricity and gas. As shown in Table 2 the only of these three industries affected by the election result was Electricity and gas. Results reported in Table 4 suggest that the two former sectors were genuinely affected by the attacks themselves as abnormal returns disappear for the post-election window, even though we need to be cautious given the reduced number of observations employed for carrying out the tests (see Table 7). The effect on the Electricity and gas sector however could be also related with the variation in the likely winner of the election that was being held three days after the attacks occurred and the fact that most companies in the sector were also connected to the PP party. This is consistent with results discussed above in Sect. 4.

Overall, given the economic literature on the impact of terrorism and the empirical results provided in this article, there is no obvious reason to think that those businesses connected to the PP would have been more directly affected by the bombings than any other company in our sample. Companies connected to the PP are from different sectors of the economy, many of them not affected directly by the terrorist attacks neither according to the literature or by the empirical results in Tables 7 and 8 .

To provide further support to the use of the two separate windows, we did test for the impact of the two-day terror attack effect on PP connected businesses, with mixed results (see Table 9). Testing the impact with M1, the model with the best goodness of fit, suggests strongly that no abnormal returns where observed in PP companies in the immediate aftermath of the terror attacks. Of the four groupings of PP connected businesses considered, only one case shows a weak significant impact, and this is at the $10 \%$ confidence interval level. However when testing the hypothesis with M2, a more simplistic model with a lower goodness of fit, the Wald test provides levels of significance across the four groupings considered, even though at varying degrees of significance between 1 and 10\% confidence interval levels. This result may be spurious given the poor goodness of fit of such model and the reduced number of observations

17 See Frey et al. (2007) and Blomberg and Hess (2008) for surveys.

18 That is clearly the case of the Basque Country in Spain, as reported by Abadie and Gardeazábal (2003). 
Table 8 Bootstrap $p$ values obtained from the 5-days election results event window model, compared to the $p$ values of the Wald test

\begin{tabular}{|c|c|c|c|c|c|}
\hline & \multicolumn{2}{|l|}{ M0 } & \multicolumn{2}{|l|}{ M7 } & \multirow[t]{2}{*}{$\mathrm{N} \times \mathrm{T}$} \\
\hline & Wald & Bootstrap & Wald & Bootstrap & \\
\hline \multicolumn{6}{|l|}{ Election results } \\
\hline Media & 0.099 & 0.119 & 0.079 & 0.086 & 15 \\
\hline Electronics & - & - & 0.095 & 0.106 & 10 \\
\hline Electricity & 0.000 & 0.001 & 0.000 & 0.002 & 30 \\
\hline Insurance & - & - & 0.070 & 0.112 & 10 \\
\hline Electricity & 0.042 & 0.091 & 0.002 & 0.022 & 12 \\
\hline \multicolumn{6}{|l|}{ Terrorist attacks } \\
\hline Minerals & 0.031 & 0.058 & 0.004 & 0.023 & 4 \\
\hline Construction materials & - & - & 0.067 & 0.113 & 4 \\
\hline Food and beverages & - & - & 0.048 & 0.101 & 12 \\
\hline Other consumption goods & - & - & 0.071 & 0.092 & 4 \\
\hline Tourism and entertainment & 0.005 & 0.030 & 0.000 & 0.007 & 6 \\
\hline Transport and distribution & - & - & 0.021 & 0.043 & 4 \\
\hline Telecommunications & - & - & 0.086 & 0.118 & 8 \\
\hline
\end{tabular}

Table 9 Impact on PP-connected businesses after the bombings

\begin{tabular}{lllll}
\hline Grouping & Type of business & M1 terrorist & M2 terrorist & $\mathrm{N} \times \mathrm{T}$ \\
\hline $\mathrm{a}$ & PP connected & $0.0682(0.0869)$ & $0.0013(0.0127)$ & 20 \\
$\mathrm{~b}$ & PP connected & 0.1225 & $0.0031(0.0244)$ & 30 \\
$\mathrm{c}$ & PP connected & 0.1845 & $0.0056(0.0486)$ & 45 \\
$\mathrm{~d}$ & PP connected & 0.2424 & $0.0095(0.0923)$ & 60 \\
\hline
\end{tabular}

Boostrap $p$ values in bracket

in the Wald test (note that the statistical significance of the results decreases when the sample size increases). In any case, the results provide at most some weak evidence for slight abnormality of the financial returns of PP-connected businesses in the immediate aftermath of the bombings, suggesting perhaps that in fact the potential change in the expectations for the election results could have started to be discounted from that point in time. This is problematic, as suggests that the use of two separate windows in the analysis may not perfectly isolate the separate impacts of the bombings and the surprise election results. In any case though, the results are clear in indicating that any potential effect observed on PP companies in the immediate aftermath of the bombings is considerably weaker than after the election, when the change in companies' profit expectations was fully confirmed with the surprise results of the general election.

\section{Conclusions}

This study shows that as a whole the forces of political convergence are quite strong. Political rhetoric in Spain is acrimonious, and memories of the 1936-1939 Century Civil War and the 1939-1975 Franco's Dictatorship are (and have increasingly been 
in the recent past) commonly used in the political debate. Post-election political evolution confirms that macroeconomic policy has not been the main political cleavage between right and left in Spain. Although President Zapatero was portrayed by the opposition as the most radical President in Spanish democratic history, the Finance Minister since 2004 was Pedro Solbes, a former EU Commissioner committed with fiscal discipline and macro-economic stability, who had also been Finance Minister in the González governments of the early 1990's, when Spain applied for membership in the Euro area. The opposition focused on nationalist tensions as the main political issue, and it concentrated on economic issues only on occasion of the takeover of the electricity firm Endesa and similar matters related to corporate control and regulatory institutions (mainly microeconomic issues ${ }^{19}$ ). The overall results are consistent with no partisanship (so no effect on expected macro policies such as fiscal policy, inflation, public expenditure or unemployment policies that may affect the market as a whole). Parties may indeed diverge in non-economic policy dimensions, such as social, religious and cultural norms, foreign policy, or the degree of institutional decentralization (for example, they bitterly fight over how to put an end to violence in the Basque Country). But the profit expectations of the stock market as a whole remained unaffected.

The results however also support the hypothesis that particular industries and businesses may be affected by the political structure of Spain and the nature of its business-politicians networks. A number of companies were indeed affected by the election results analysed in this article, and the empirical results provide some support to the hypothesis that the degree of political connectedness of such businesses is at the core of explaining the impact of the surprise election results on their financial returns. Our exercise is based on the event study methodology, which depends on market expectations and, in particular, the results are meaningful only to the extent that the semi-strong version of the efficient financial markets hypothesis holds. Besides, partisan macroeconomic effects could have an impact on agents that are not the investors in quoted firms, but workers, consumers, or investors in other firms.

Differences over economic policies between right and left vary over time and across countries; in 2004 in a Euro-area country such as Spain, there was no clear and robust evidence of significant differences. However, capture and political connections, jointly with agency problems within companies, appear to have had a significant impact on those firms where such conditions were present, particularly when such connections were with the incumbent Government.

Open Access This article is distributed under the terms of the Creative Commons Attribution License which permits any use, distribution and reproduction in any medium, provided the original author(s) and source are credited.

\section{Appendix}

See Tables 10 and 11.

19 Although in February 2007 the two main political parties were reaching an agreement on takeover and competition policy legislations. 
Table 10 Companies grouped by industries

\begin{tabular}{|c|c|}
\hline Economic sector & Company \\
\hline \multirow[t]{2}{*}{ Oil } & Cepsa \\
\hline & Repsol \\
\hline \multirow[t]{6}{*}{ Electricity and qas } & Endesa \\
\hline & Enaqas \\
\hline & Iberdrola \\
\hline & Gas Natural \\
\hline & Red Eléctrica \\
\hline & Unión Fenosa \\
\hline Water and others & - \\
\hline \multirow{2}{*}{$\begin{array}{l}\text { Minerals, metals and transformation } \\
\text { of metal products }\end{array}$} & Acerinox \\
\hline & Turbacex \\
\hline \multirow[t]{5}{*}{ Machinery goods } & Azkoyen \\
\hline & Garmesa \\
\hline & Duro Felguera \\
\hline & Mecalux \\
\hline & Zardoya Otis \\
\hline \multirow[t]{5}{*}{ Construction } & $\mathrm{ACS}$ \\
\hline & Acciona \\
\hline & FCC \\
\hline & Ferrovial \\
\hline & Sacyr Vallehermoso \\
\hline \multirow[t]{2}{*}{ Construction materials } & Portland \\
\hline & Uralita \\
\hline Chemical industry & - \\
\hline Enqjneerinq & - \\
\hline Aerospacial & - \\
\hline \multirow[t]{6}{*}{ Food and Beverages } & Campofrio \\
\hline & Ebro Puleva \\
\hline & Natra \\
\hline & Pescanova \\
\hline & SOS Cuetara \\
\hline & Viscofan \\
\hline \multirow[t]{4}{*}{ Clothes } & Adolfo Dominguez \\
\hline & Dogi \\
\hline & Inditex \\
\hline & Sniace \\
\hline \multirow[t]{5}{*}{ Paper and Graphic Arts } & Ence \\
\hline & Iberpapel \\
\hline & Miquel i Castas \\
\hline & Europac \\
\hline & Unipapel \\
\hline Cars & - \\
\hline \multirow[t]{4}{*}{ Pharmaceutical and Biotechnology } & Puleva Biotech \\
\hline & Faes \\
\hline & Natraceutical \\
\hline & Zeltia \\
\hline \multirow[t]{2}{*}{ Other consumption goods } & Altadis \\
\hline & Vidrala \\
\hline
\end{tabular}


Table 10 continued

\begin{tabular}{|c|c|}
\hline Economic sector & Company \\
\hline Toruisrn and entertainment & $\begin{array}{l}\text { NH Hoteles } \\
\text { Sol Melia } \\
\text { Telepizza }\end{array}$ \\
\hline Trade & - \\
\hline Media & $\begin{array}{l}\text { Prisa } \\
\text { Sogecable } \\
\text { TPI }\end{array}$ \\
\hline Transport and distribution & $\begin{array}{l}\text { Iberia } \\
\text { Logista }\end{array}$ \\
\hline Highways and parkings & $\begin{array}{l}\text { Abertis } \\
\text { Europistas }\end{array}$ \\
\hline Other services & - \\
\hline Banking & $\begin{array}{l}\text { Banco Andalucia } \\
\text { BBVA } \\
\text { Bankinter } \\
\text { Banesto } \\
\text { Banco Valencia } \\
\text { Banco de Credito Balear } \\
\text { Banco Guipuzcoano } \\
\text { Banco Pastor } \\
\text { Banco Popular } \\
\text { Banc Sabadell } \\
\text { BSCH }\end{array}$ \\
\hline Insurance & $\begin{array}{l}\text { Catalana Occidente } \\
\text { Mapfre }\end{array}$ \\
\hline Financial investment and holding & - \\
\hline Real Estate & $\begin{array}{l}\text { Inmocaral } \\
\text { Colonial } \\
\text { Metrovacesa } \\
\text { Urbis }\end{array}$ \\
\hline Telecommunications & $\begin{array}{l}\text { Tecnocom } \\
\text { Jazztel } \\
\text { Telefonica } \\
\text { Telefonica moviles }\end{array}$ \\
\hline Electronics and software & $\begin{array}{l}\text { Amper } \\
\text { Indra }\end{array}$ \\
\hline Technological hardware & - \\
\hline
\end{tabular}

Table 11 Companies connected under each grouping

\begin{tabular}{ll}
\hline Grouping a & \\
Abertis, S.A. & Mixed strategy \\
Banco Santander, S.A. & Mixed strategy \\
Endesa, S.A. & PP \\
Metrovacesa S.A. & PP \\
Red Electrica Corporacion, S.A. & PP \\
Repsol YPF, S.A. & PP \\
Sogecable & PSOE \\
Sol Melia,S.A. & Mixed strategy \\
Grouping b & \\
Adolfo Domínguez, S.A. & PSOE \\
Endesa, S.A. & PP \\
Iberia, Lineas Aereas de España, S.A. & PP \\
Jazztel, P.L.C. & Mixed strategy \\
\hline
\end{tabular}


Table 11 continued

\begin{tabular}{ll}
\hline Metrovacesa S.A. & PP \\
Natraceutical,S.A. & PP \\
Red Electrica Corporacion, S.A. & PP \\
Repsol YPF, S.A. & PP \\
Sol Melia,S.A. & Mixed strategy \\
Tecnocom, Telecomunicaciones y Energia, S. & Mixed strategy \\
Turbacex & PNV
\end{tabular}

Grouping c

Abertis, S.A.
Acciona, S.A.
ACS, S.A.

Mixed strategy

Banco de Valencia

PSOE

PP

Banco Santander, S.A.

PP

Enagas, S.A.

PP

Endesa, S.A.

PP

Gas Natural Sdg, S.A.

PP

Metrovacesa S.A.

Mixed strategy

Red Electrica Corporacion, S.A.

PP

Repsol YPF, S.A.

$\mathrm{PP}$

Sogecable

$\mathrm{PP}$

Sol Melia, S.A.

PSOE

Telefonica moviles

Mixed strategy

Telefonica, S.A.

Mixed strategy

PP

Grouping d

Acciona, S.A.

PSOE

ACS, S.A.

PP

Adolfo Domínguez, S.A.

PSOE

Banco de Valencia

PP

Enagas, S.A.

$\mathrm{PP}$

Endesa, S.A.

$\mathrm{PP}$

Gas Natural Sdg, S.A.

Iberia, Lineas Aereas de España, S.A.

Mixed strategy

Jazztel, P.L.C.

Logista

PP

Metrovacesa S.A.

PP

Natraceutical, S.A.

$\mathrm{PP}$

Red Electrica Corporacion, S.A.

PP

Repsol YPF, S.A.

PP

Sogecable

PP

Sol Melia,S.A.

PSOE

Tecnocom, Telecomunicaciones y Energia, S.

Mixed strategy

Telefonica moviles

Mixed strategy

Mixed strategy

Telefonica, S.A.

PP

Turbacex

PNV

Uralita, S.A.

Mixed strategy

Viscofan, S.A.

PP 


\section{References}

Abadie A, Dermisi S (2008) Is terrorism eroding agglomeration economies in Central Business Districts? Lessons from the Office Real Estate Market in Downtown Chicago. J Urban Econ 64:451-463

Abadie A, Gardeazábal J (2003) The economic costs of conflict: a case study of the Basque Country. Am Econ Rev 93(1):113-132

Abadie A, Gardeazábal J (2008) Terrorism and the world economy. Eur Econ Rev 52:1-27

Alesina A, Rosenthal H (1995) Partisan politics, divided government and the economy. Cambridge University Press

Bel G, Trillas F (2005) Privatization, corporate control and regulatory reform: the case of Telefónica? Telecommun Policy 29:25-51

Bergman T (1995) Constitutional rules and party goals in coalitions formation. An analysis of winning minority governments in Sweden. Umea Universiteit

Binder JJ (1985) Measuring the effects of regulation with stock price data. RAND J Econ 16(2):167-183

Binder JJ (1998) The event study methodology since 1969. Rev Quant Finance Account 11:111-137

Blomberg SB, Hess GD (2008) Economics of terrorism, 2nd edn. New Palgrave Dictionary of Economics

Boix C (1996) Partidos políticos, crecimiento e igualdad. Estrategias económicas conservadoras y socialdemócratas en democracias avanzadas. Alianza Editorial, Madrid

Boubakri N, Cosset JC, Saffar W (2008) Political connections of newly privatized firms. J Corp Finance 14:654-673

Chou P (2004) Bootstrap tests for multivariate event studies. Rev Quant Finance Account 23:275-290

Downs A (1957) An economic theory of democracy. Harper and Row, New York

Effron B (1979) Bootstrap methods: another look at the Jacknife. Ann Stat 7:1-26

Enders WK, Sandler T (1991) Causality between transnational terrorism and tourism: the case of Spain. Terrorism 14(1):49-58

Enders WK, Sandler T (1996) Terrorism and foreign direct investment in Spain and Greece. Kyklos 49:331352

Enders W, Sandler T, Parise GF (1992) An econometric analysis of the impact of terrorism on tourism. Kyklos 45(4):531-554

Faccio M (2006) Politically connected firms. Am Econ Rev 96(1):369-386

Ferguson T, Voth HJ (2008) Betting on Hitler-the value of political connections in Nazi Germany. Q J Econ 123(1):101-137

Ferreira F, Gyourko J (2009) Do political parties matter? Evidence from US Cities. Q J Econ 124(1):399_ 422

Fisman R (2001) Estimating the value of political connections. Am Econ Rev 91(4):1095-1102

Frey BS, Luechinger S, Stutzer A (2007) Calculating tragedy: assessing the costs of terrorism. J Econ Surv 21(1): $1-24$

Füss R, Bechtel M (2006) Partisan politics and stock market performance: the effect of Expected Government Partisanship on stock returns in the 2002 German Federal Election. mimeo

García Montalvo J (2011) Voting after the bombing: a natural experiment on the effect of terrorist attacks on democratic elections. Rev Econ Stat 93(4):1146-1154

Goldman E, Rocholl J, So J (2008) Do politically connected boards affect firm value? Rev Financ Stud 22(6):2331-2360

Grossman JM, Helpman E (2002) Special interest politics. MIT Press

Herron MC (2000) Estimating the economic impact of political party competition in the 1992 British Election. Am J Polit Sci 44(2):326-337

Herron MC, Lavin J, Cram D, Silver J (1999) Measurement of political effects on the United States Economy: a study of the 1992 Presidential Election. Econ Polit 11(1):51-81

Hibbs DA (1977) Political parties and macroeconomic policy. Am Polit Sci Rev 71:1467-1487

Horowitz JL (2001) The bootstrap. Handbook of econometrics, vol 5. North Holland, pp 3159-3228

Hotelling H (1929) Stability in competition. Econ J 39(153):41-57

Jayachandran S (2006) The Jeffords effect. J Law Econ XLIX:397-425

Jensen NM, Schmith S (2005) Market responses to politics: the rise of Lula and the decline of the Brazilian stock market. Compar Polit Stud 38(10):1245-1270

Khotari SP, Warner JB (2007) Econometrics of event studies. Handbook of corporate finance: empirical corporate finance, Chap 1 
Laver M, Schofield N (1998) Multiparty government: the politics of coalition in Europe. The University of Michigan Press

Leblang D, Mukherjee B (2005) Government partisanship, elections, and the stock market: examining American and British stock returns, 1930-2000. Am J Polit Sci 49(4):780-802

MacKinlay AC (1997) Event studies in economics and finance. J Econ Lit 35:13-39

Pantzalis C, Stangeland DA, Turtle HJ (2000) Political elections and the resolution of uncertainty: the international evidence. J Bank Finance 24:1575-1604

Persson T, Tabbellini G (2000) Political economics. Explaining economic policy. The MIT Press

Petterson-Lidbom P (2008) Do parties matter for economic outcomes? A regression-discontinuity approach. J Eur Econ Assoc 6(5):1037-1056

Reniu JM (2001) Las teorías de las coaliciones políticas revisadas: la formación de gobiernos minoritarios en España, 1977-1996. Universitat de Barcelona

Richardson HW, Gordon P, Moore JE, Kim S, Park J, Pan Q (2007) Tourism and terrorism: the national and interregional economic impacts of attacks on major US theme Parks. In: Richardson HW, Gordon P, Moore JE (eds) The economic costs and consequences of terrorism. Edward Elgar

Riker WH (1962) The theory of political coalitions. Greenwood Publishing Group

Roberts BE (1990) Political institutions, policy expectations, and the 1980 election: a financial market perspective. Am J Polit Sci 34(2):289-310

Roemer JE (2001) Political competition. Theory and applications. Harvard University Press

Shum PM (1995) The 1992 Canadian constitutional referendum: using financial data to assess economic consequences. Can J Econ 28(4):794-807

Trillas F (2004) The structure of corporate ownership in privatized utilities. Investigaciones Económicas XXVII(2):257-284

Trillas F (2010) Corporate control in the electricity industry. In: Jiménez JC, García Delgado JL (eds) Energy regulation in Spain: from monopoly to market. Thomson Civitas

Tversky A, Kahneman D (1991) Loss aversion in riskless choice: a reference dependent model. Q J Econ 106:1039-1061

Vuchelen J (2003) Electoral systems and the effects of political events on the stock market: the Belgian case. Econ Polit 15(1):85-102 